\title{
Excision Repair
}

National Cancer Institute

\section{Source}

National Cancer Institute. Excision Repair. NCI Thesaurus. Code C16566.

Excision Repair mechanisms remove and replace damaged nucleotides from DNA molecules with new nucleotide subunits, e.g., Base Excision Repair, Nucleotide Excision Repair, or SOS Function. 